\title{
Scenario Analysis and Proposed Plan for Pakistani Universities - COVID - 19: Application of Design Thinking Model
}

\author{
Waqar Akram \\ Professor of Economics \\ Sukkur IBA University, Pakistan \\ waqar.akram@iba-suk.edu.pk \\ Corresponding Author \\ Sultan Adeel \\ Student MS Program \\ Sukkur IBA University, Pakistan \\ sultan.adeel@iba-suk.edu.pk \\ Muhammad Mudassar Tabassum \\ Deputy Manager - Business Intelligence (Data Analyst) \\ Beaconhouse School System \\ muhammad.mudassir@bh.edu.pk \\ Yuansheng Jiang \\ Chengdu 611130, China \\ yjinag@sicau.edu.cn \\ Abbas Ali Chandio \\ Postdoctoral Research Fellow
}

College of Economics, Sichuan Agricultural University,

College of Economics, Sichuan Agricultural University, China alichandio@sicau.edu.cn

Iram Yasmin

Assistant Professor

Govt. College Women University, Faisalabad.

iram.yasmin220@yahoo.com 


\section{Abstract}

The outbreak of a novel Corona Virus 2019 (COVID-19) has plumped the educational system of the world and have impacted 1.4 billion learners across the globe. Therefore, there is a gap for researchers to develop a system they may sustain during this current pandemic and in the future. In this paper, the researchers have worked on developing the "Virtual Learning Environment" by undertaking the scenario analysis in the design thinking model (DTM). The literature has also supported the notion that the Virtual Learning Environment (VLE) gives the same satisfaction as of the traditional learning education (TLE). The brainstorming was done for the scenario analysis, and digital responses of the students were taken to develop the framework. The results, in the shape of the framework, has highlighted the three main stakeholders, i.e., teachers, students, and virtual system. Based on the results, each university can plan and develop a similar system for higher education in Pakistan.

Keywords: COVID-19, Virtual Learning System, Traditional Learning System, Technology, Universities.

\section{Introduction \& Background}

In December 2019, the initial infected cases of a novel coronavirus disease (COVID-19) were first reported in Wuhan, China. Presently, the coronavirus disease (COVID-19) has spread to 209 countries, as of April 07, 2020, there have been 1.3 million reported cases across the globe and more than 4000 cases in Pakistan (Worldometer, 2020; NIHP, 2020). The novel COVID-19 disease is a critical issue of developing and developed countries. The COVID-19 is rapidly spreading around the world and many scientists as well as researchers have been investigating the nature of novel coronavirus and evaluating the short-term and long-term impacts of this disease. This virus is adversely affecting all economic sectors as well education system around the world. The UNESCO reports that 1.4 billion learners across the globe are severely impacted by the shutdown of schools, colleges, and universities (McCarthy, 2020). Further, the reopening of these institutions is not defined as the worldwide condition of the COVID-19 is worsening day by day.

The most optimistic projections suggest the return to the usual conditions in the coming three months despite the trillions of investments to halt the crisis. However, the pessimistic predictions predict at least one year of "abnormal conditions" in the global educational system and the return of students to universities nearly after five years (INOMICS, 2020).

Therefore, the universities in the developed nations are somehow capable of coping with the skyrocketing issue of student's education with the help of technology, specifically, excellent internet facilities and students' response. On the contrary, universities in the developing nations are finding it hard to deal with online teaching owing to the internet facility and limited bandwidth, electricity issues, and students' responsiveness. However, this outbreak has also opened the number of opportunities, as 
like the 2008 - 09 crisis, to be proactive and help the country's journey. Thus, each university and institution must realize that they can strategically improve their ability to respond to this shock now and in the future. It will also help them grow and sustain globally.

In Pakistan, the Higher Education Commission (HEC) concerns to minimize the loss of the students during this lockdown. The HEC, founded in 2002, is the supreme autonomous body for funding, overseeing, regulating, and accreditation the higher educational institutions in Pakistan (HEC, 2020). It has recognized the 83 private and 128 public sector universities across Pakistan. The enrollment percentage at the tertiary level is 1.58 million (8 percent) (ESP, 2018-19; WDI, 2020). Along with this, Pakistan has allocated the budget of PKR 77.3 billion for the education affairs and services during the fiscal year 2019 - 20. Out of this, PKR 28.64 billion has been allocated for HEC, PKR 2.83 billion for the primary education section, and PKR 6.72 billion for the secondary education sector (Amin, 2019). The trends of total public expenditure on education in PKR billion and \% of GDP have been exhibited in Figures 1 and 2.

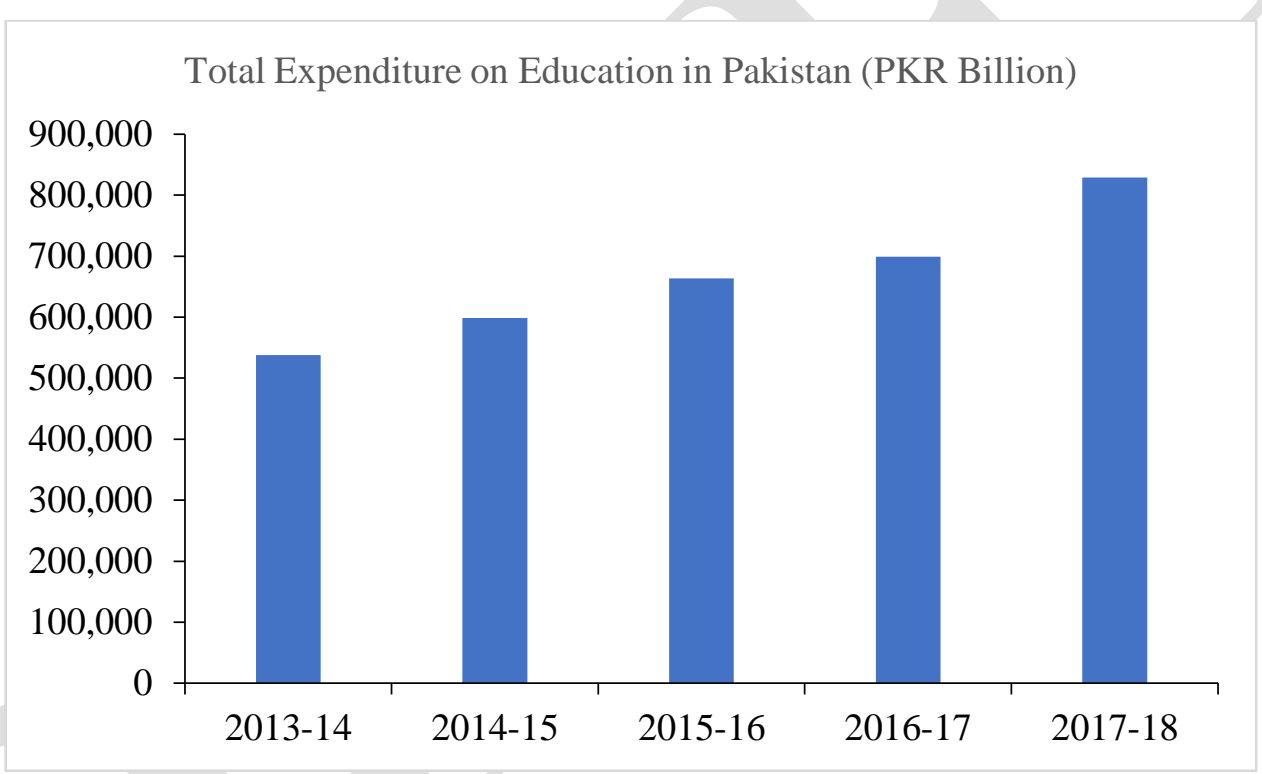

Fig. 1 Trend of total expenditure on education in Pakistan (PKR Billion)

Source: Economic Survey of Pakistan (2018-19) 


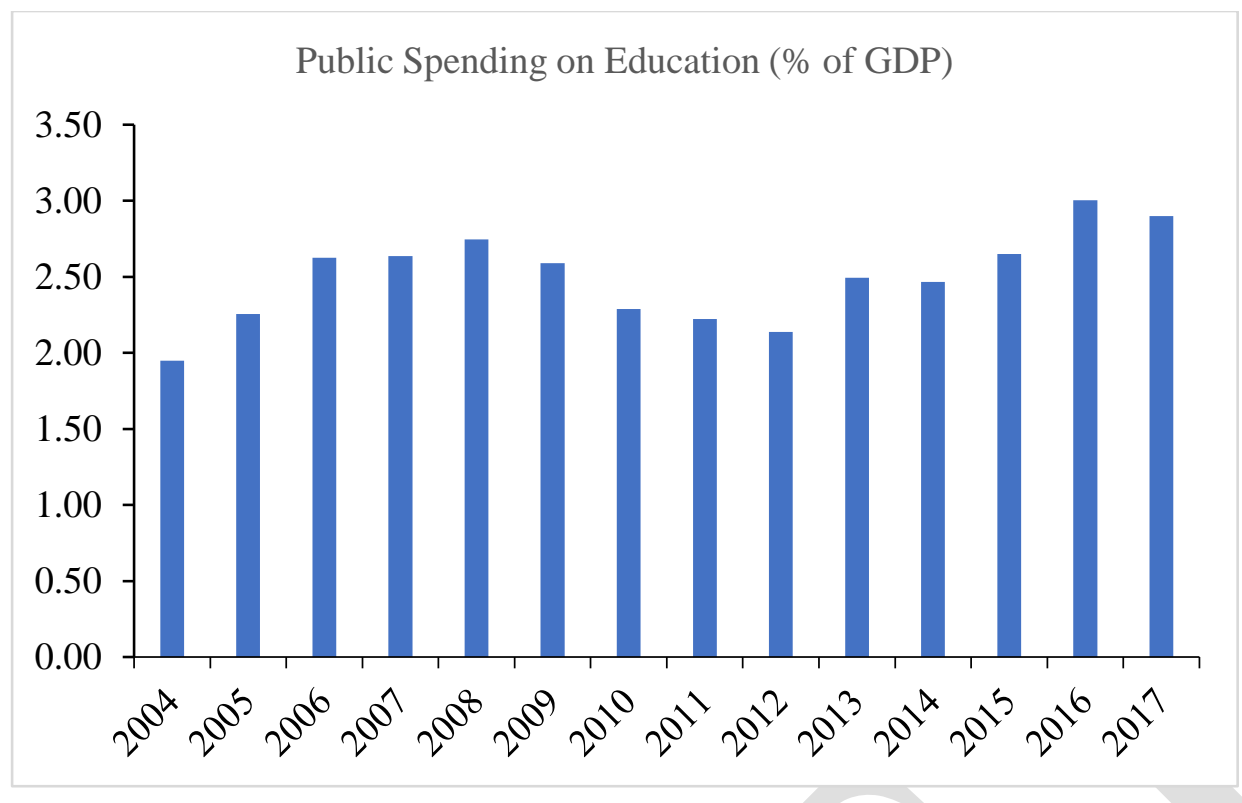

Fig. 2 Trend of public spending on education in Pakistan (\% of GDP)

Source: World Bank (2017)

In Pakistan, universities are based on traditional learning (T-Learning) model of education where the teacher is solely responsible for running the class based on his learnings, understanding, and experiences, whereas, the students are at the receiver's end (passive) who listen and take notes only (Shimamoto, 2012). This learning is associated with the classrooms where the meeting of both stakeholders is predefined. It is based on the chalk and talks learning session, aided by textbooks and teaching notes, and utilizes seatwork, observation, and listening as the methods for delivery (Halili, 2018; Sarrab, 2019). The TLE does not give much power to students to decide the learning methods, and they are limited to the available resources, text, and information given by the instructor (Means et al., 2009). However, the universities in Pakistan are integrating the LMS, which has also changed the distance education learning Bervell \& Arkorful (2020).

On the other hand, the Virtual Learning Environment (V-Learning) is another model for the education that is used by some of the tertiary educational institutions in Pakistan. It is a web-based or software application learning model that allows instructors to teach learners through virtual classrooms regardless of their presence (Sarrab, 2019). This system brings students and teachers at the same level. It allows students to learn from different tools from anywhere at any time (Halili, 2018). In this model, students can easily access the course contents, get help from their instructors, share the documents, and use the discussion forums (Martins \& Kellermanns, 2004). The education sector is widely using it, as it has become an integral part of tertiary education worldwide (Trowler, 2010). The virtual learning method had provided an effective learning method for learners who prefer to take classes online (Song \& Deng, 2019).

Currently, the students are using digital resources to ease the learning process and learn from different sources. However, Mercader \& Gairín (2020) argue that these technologies are not used by the teachers 
in the educational sector, which creates a gap between students and teachers. Therefore, in order to develop a virtual learning environment, there is a need to train teachers on how to use digital technologies.

Unfortunately, owing to the outbreak of COVID-19 and imposed lockdown all over the world, we are only left with the option of a virtual learning model in the educational sector. That is why, in this paper, we are only undertaking the virtual learning model for examination, to check whether it can aid in reducing the educational loss or not. Besides, we are thankful to the inventors of these technologies that had been aiding, though very slowly, in the educational sector, have now become the pearl in the desert.

\section{Research Questions:}

How to overcome the challenges of virtual education after pandemic (COVID-19) in Pakistan?

The objective of this paper is to help universities in Pakistan to prepare and design a proper plan to meet the challenges of COVID-19.

\section{Literature Review}

Since the 1990s, after the development of the internet, the emergence of tech-based companies and the web-based world has changed the teaching. The rise and improvement in the "Information and Communication Technology" (ICT) has enhanced learning through the internet. It has allowed the learning to become dynamic and interactive (Dávideková et al., 2017). Currently, every educational institution is applying modern technology in facilitating education and students. The involvement of information technology in education has made education faster and reliable (Abdollahi, 2018). Halili (2019) quotes that the involvement of technologies including virtual and augmented reality, cloud computing, multi-touch LCD screens, internet of things (IoT), blockchain, and artificial intelligence, in teaching has improved the teaching process.

Halili at al. (2018) examined the students' level of engagement in different learning environments, i.e., traditional and virtual. They undertook four dimensions; behavioral, cognitive, emotional, and agentic engagement. Their findings predicted the high level of engagement of the virtual learning environment in comparison to the traditional learning environment. However, they suggested working on the effectiveness of virtual learning environment in classrooms. Likewise, Colis \& Moonen (2001) have argued that the shift from TLE to VLE has given the flexible learning environment to both stakeholders, i.e., teachers and students, by changing the time used, way of lecture delivery and the information availability.

Another group of researchers conducted the study at an Australian university to investigate the students' satisfaction and scores for traditional and mixed (traditional combined with e-learning) learning methods. An experiment was organized comparing the scores and satisfaction level of two distinct groups of tertiary level students. One group experiences the traditional learning model, whereas, another group received the mixed learning method. The results depicted the significantly improved scores and 
satisfaction of students who were part of the mixed learning method in comparison to the traditional learning method. Based on these results, they suggested integrating the virtual learning tools to increase the confidence level, competence, and satisfaction level of students (Ariana et al., 2016).

Halili (2019) reviewed the involvement of digital advancement in the educational sector after the industrial revolution 4.0 in Malaysia. He concludes that the involvement of digital tools in teaching and learning enhances the performance of the education system owing to the inclination of students towards technology. Therefore, he suggested policymakers to develop a policy for the usage of contemporary technology in the enhancement of students' learning. Other research, including Halili et al., 2018; Halili \& Suguneswary, 2016; Halili \& Hamidah, 2016; Maryam \& Halili, 2015 also explained that the increased usage of technology in education had improved the learning of students.

Dávideková et al. (2017) conducted the study to investigate the status of virtual reality in the education of employees working in Slovakia. They emphasized the usage of VR in education as it will bring in clarity, demonstrativeness, and appeal. Results revealed that the TR is more time consuming, monotonous, lacks demonstrativeness, and boring. Likewise, Fernandez (2017) conducted a study on ways to improve the involvement of augmented and virtual reality in education. He has highlighted the involvement of experiential modes to improve the use of technology as these technologies improve the online teaching, in-person class sessions, training, and understanding of concepts. However, the limited adoption of these technologies and the training of instructors play the role of barriers to these technologies in education. Further, he has also suggested the six-step adoption process of technology. These are as follows: Teachers' training, development of conceptual prototypes, teamwork, programmer, educational architect, and the experience of production.

Abdollahi (2018) compared the efficacy of traditional and virtual learning methods in education in Iran by making the two distinct groups of students. The former group of students chose the traditional method for learning, and the latter chose the virtual learning method. The results exposed the similar effectiveness of virtual learning methods to traditional learning methods. However, this study did not consider the students' satisfaction as a variable. Hence, they concluded that the involvement of virtual learning could be as effective as the traditional learning method. Further, Ruiz et al. (2006) highlighted that learning through electronic means provides valuable opportunities to students. Whereas, AlNeklawy (2017) emphasized that traditional learning does not give time to look for deep learning.

Phungsuk et al. (2017) conducted a study to develop a problem based virtual learning environment for undergraduate students. The developed model predicted that it supports and increases the learning of students, problem-solving skills, and achievements. Hence, based on the model, an experiment revealed that the students who opted to problem-based VLE scored quite high in tests compared to the students who opted in the traditional learning environment. Another assessment showed that the students who opted for VLE had gained more up to date knowledge in comparison to their counterparts. Therefore, 
they concluded that the VLE model allows students to gain higher satisfaction and involve with their instructor owing to the more accessible and informal communication.

Likewise, another group of researchers conducted the study to compare the pharmacy students' learning on drugs wither via lessons or recorded lectures. The students who received and learned through the recoded performed better than those who were taught by lessons (Wisniewski \& Hortman, 2019).

Further, Renz \& Hilbig (2020) have concluded that the increasing number of tech companies has revamped the traditional learning with the help of software. However, there is not any worth talking business who has undertaken the AI to transform teaching and learning. Likewise, Medina et al. (2019) have concluded that the food sciences and nutrition programs at the higher education level have shown the slow growth to transform into the online learning program owing to the required communication with peers, management of social networks, and digital skills. Besides, they have also argued that the realities of online education have been explored, and these are; connectivity issues, the managerial capability of universities, and lack of confidence.

\section{Methodology and Data}

The research design of this paper was based on the scenario analysis in which the researcher has initially analyzed the scenario developed after the outbreak of the novel COVID-19 and predicted the probable future consequences. This scenario analysis is used to predict and analyze the impact of probable future events and its consequences, assuming that the current condition may prevail in the future (Kishita, 2017; Balaman, 2019). It can be used to predict the performance and behavior of a particular system when opened to any unexpected event(s).

We used the scenario based on the dimensions and scenarios defined by Prof. Friga-Scenario Planning for Coronavirus, March 13, and McKinsey \& Company-Global Health + Crises Response Team, Feb 28, respectively. Quick Response: (Best Case) Quick-recovery scenario predicts that outbreaks grow until the second quarter of 2020 but begin to slow; the economic impact is mostly felt in the first quarter and will bounce back to normalcy in the second quarter. Global Slowdown: (Base Case) Global slowdown envisions a significant slowdown through the third quarter of this year, with China controlling and restarting its supply chain in the second quarter. Impact on sectors will vary based upon the magnitude of transmission, the death rate, seasonality effects, and consumer reaction. Hardest-hit areas will be aviation, tourism, hospitality, and consumer goods. Global Pandemic \& Recession: (Worst Case) Global pandemic and recession would result in economic malaise through the end of 2020, with widespread interruptions in supply chains, air travel, and the like and continued community outbreaks. We used five dimensions under these three scenarios named teachers, operations, community, financial, and research. 


\section{Design Thinking Model (DTM):}

After analyzing the situation of higher education in Pakistan, we have used the DTM method with the help of mind manager software (MMS), to develop the virtual learning model (VLM) of education in Pakistan. Plattner and Kelley developed this model in 2004, which has changed the way to solve the problems, particularly problems faced by humans in a human-centric way (Haffman, 2016). It is used to create innovative solutions to the prevailing problems with the help of the five-step process: empathize, define, ideate, prototype, and test, respectively (Dam \& Teo, 2020).

\section{Data Collection:}

For this paper, we performed the brainstorming at the initial stage to define the probable consequences of COVID-19 in the educational sector of Pakistan. We discussed with faculty and staff member of Public Sector universities. Later, we collected the online responses of the students who are the primary stakeholder of this sector.

\section{Pakistani Universities Connected in Virtual Space}

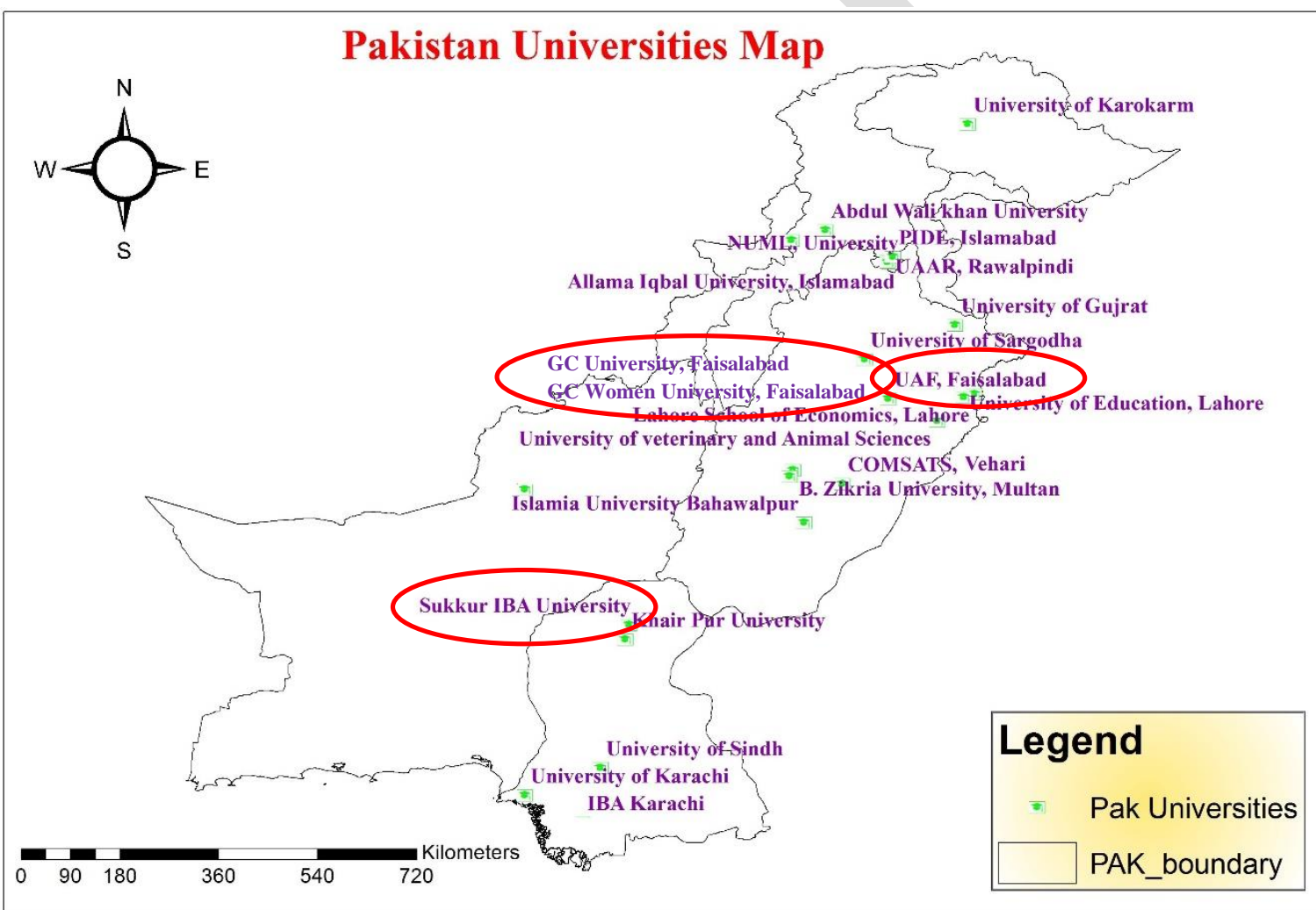




\section{Results}

\section{Scenario Analysis and Higher Education Sector in Pakistan:}

For now, unfortunately, we have ruled out the best scenario (quick economic response) case — things will not get better quickly for Pakistani Universities, owing to the sudden rise in the COVID-19 cases (more than 4000 cases in Pakistan and 1.3 million globally, as of April 07, 2020) reported by National Institute of Health, Pakistan and worldometer website, respectively. Furthermore, Pakistan government passed the orders to close universities and other educational institutions till May 30, 2020, which assures that the universities will stay closed for the next two months, and there will not be any possible face to face interaction possible between students and teachers; no brick and mortar education.

\section{Best Case Scenario and Impact on Higher Education Sector:}

The next "seems possible" scenario is global and national economic slowdown (Base Scenario) that will impact the teaching across all academic programs in spring 2020.

In this case, Teachers will be impotent to teach face-to-face, give assignments, conduct and evaluate exams, and give feedback online. Whereas, in the context of university operations, seemingly, many employees, especially teachers, and other managerial staff will suffer significantly, as they will not find the same office environment to work, the same colleagues to roam around and gossip, and the management of work-life tensions. Likewise, a lot of academic and research conferences, seminars, and co-curricular and extra-curricular events, which were supposed to happen during the spring 2020 semester, will get canceled. Further, the entire education community-students, teachers, and managerial staff, will stay at home and face the workload stress and depression. On the financial side, in particular, there will be a shortage of finances as teachers and managerial staff will be working from home.

Conversely, there will not be any cash inflows activity in the universities. Besides, an abrupt rise in the acquisition of the online facilities will cost a lot, making the finances worse. Lastly, on the research side, there will be an impact on market-based research where the responses cannot be taken virtually. Other research, including online data fetching (experiments) and analysis, may increase as the researchers may find more time to do analysis.

If the situation prevails, which data indicates, which is cynical-a worst-case scenario, pray for not, drastically affect the teaching during spring, fall, and even on the recurring spring semester 2021. It will be highly challenging for both the teachers and students to continue in-person class sessions, even after the revival. However, it will not be that much easier to maintain online classes for that long period; online teaching will also cost a lot in the shape of internet and related facilities costs. Similarly, in operations, a drastic shutdown will disable employees to do everything from their homes; working from home will be very difficult. Universities will not be able to conduct exams and induct students in the fall semester and the recurring spring semester 2021. The educational community will also suffer a lot. 
There will not be any academic and research-based activity, conferences, seminars, and co-curricular and extra-curricular events throughout the academic year.

Further, as the lockdown prolong, there will be a rise in depression and anxiety among stakeholders. In this case, the worst-hit area will be the finances, as there will be only probable outflows. Further, there may be a sudden increase in the analysis-based research in which the data can be fetched from online sources, and analysis can be done indoor. However, there will be a downfall in the research that includes the responses, i.e., focus group discussion, survey-based research. 
Scenario Analysis: Table 1.

\begin{tabular}{|c|c|c|c|}
\hline $\begin{array}{l}\text { Context } \\
\text { Variables }\end{array}$ & $\begin{array}{c}\text { Quick Recovery } \\
\text { (Not possible now) }\end{array}$ & $\begin{array}{l}\text { Global Slowdown } \\
\text { (Seems possible) }\end{array}$ & $\begin{array}{c}\text { Global Pandemic \& Recession } \\
\text { (Most probably) }\end{array}$ \\
\hline Teaching & Ruled Out & $\begin{array}{l}\text { Spring semester activities halted. No face to face interaction and universities } \\
\text { closed for the time being. Shift to online classes with the help of Zoom-LMS. } \\
\text { Synchronous and asynchronous may be tried. Assignments \& take home- } \\
\text { based open book exams may be used as an option. Evaluation based upon } \\
\text { these instruments - no exam hall and invigilation. }\end{array}$ & $\begin{array}{l}\text { The summer session ruled out and even recurring fall semester. Would } \\
\text { be highly challenging for teachers and students to shape back in the } \\
\text { position of face to face learning. However, cost on internet use and } \\
\text { related facilities shows an upward trajectory }\end{array}$ \\
\hline Operations & Ruled Out & $\begin{array}{l}\text { All the stakeholders, for example, teachers, staff, and management, remain } \\
\text { in an uncertain situation and are supposed to work from home. The } \\
\text { collaborative activities organized by faculty and staff suffer significantly, } \\
\text { like conferences and sports events that are supposed to happen during } \\
\text { spring. May go online but again challenging. }\end{array}$ & $\begin{array}{l}\text { The next intake for the universities becomes impossible, may fall } \\
\text { significant enrollment no during fall and recurring spring semester. For } \\
\text { operations, the employees may not be able to perform all duties from } \\
\text { home efficiently and effectively. }\end{array}$ \\
\hline Community & Ruled Out & $\begin{array}{l}\text { The stakeholders of universities, i.e., students, teachers, and managerial } \\
\text { staff, are staying at home and facing the workload stress and fear of disease } \\
\text { and depression. Faculty would not be able to focus on research. }\end{array}$ & $\begin{array}{l}\text { If, unfortunately, the lockdown situation prevails, that may cause } \\
\text { severe depression, anxiety, and workload stress. The research labs } \\
\text { become unfunctional that hurts research-based activities and, of course, } \\
\text { academic activities. }\end{array}$ \\
\hline Financials & Ruled Out & $\begin{array}{l}\text { There is a shortage of finances as teachers, and managerial staff is working } \\
\text { from homes, and on the other hand, there is not any cash inflow activity. } \\
\text { The government only provides funds for salary and pensions. In the short } \\
\text { run, universities may short of funds from } 0.5 \text { to } 4.9 \text { percent. (Prof. Friga } \\
\text { estimates). }\end{array}$ & $\begin{array}{l}\text { Finances become unmanageable due to only outflows and uncertain } \\
\text { and risky market conditions. Government, philanthropists, and } \\
\text { business support may stop. On the other hand, there is a } 5 \text { percent to } 50 \\
\text { percent reduction in the operating expenses of the university. (Prof. } \\
\text { Friga estimates). }\end{array}$ \\
\hline Research & Ruled Out & $\begin{array}{l}\text { There is an impact on market-based research where the responses cannot be } \\
\text { taken virtually. Other research, including online data fetching } \\
\text { (experiments) and analysis, may increase as the researchers may find more } \\
\text { time to do analysis. }\end{array}$ & $\begin{array}{l}\text { It is expected that there is a sudden increase in the analysis-based } \\
\text { research in which the data can be fetched from online sources, and } \\
\text { analysis can be done indoor. However, there is a downfall in the } \\
\text { research that includes the responses, i.e., focus group discussion, } \\
\text { survey-based research. }\end{array}$ \\
\hline
\end{tabular}




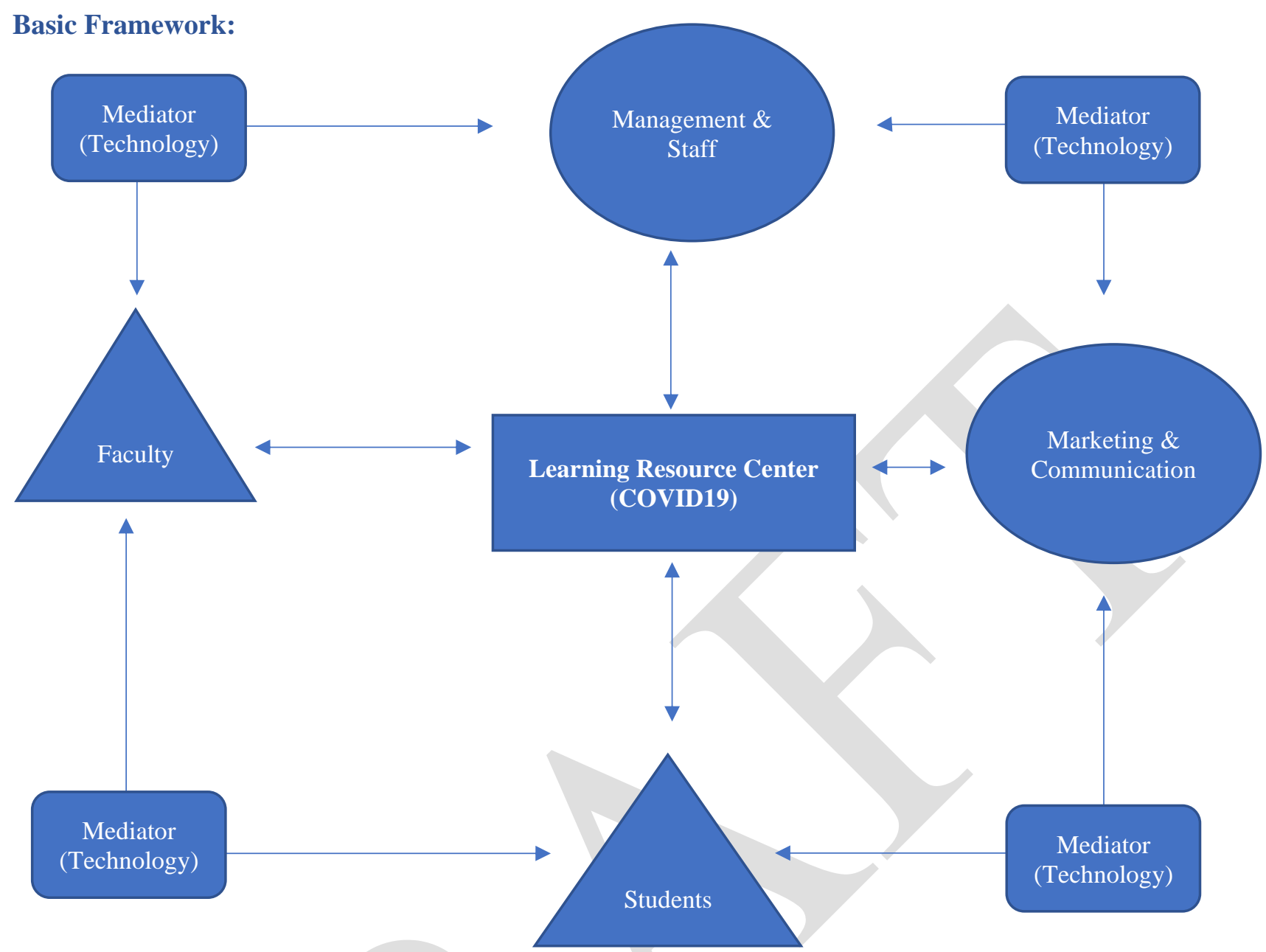

Fig. 3 Basic Framework

Source: Developed by Researchers

The developed framework puts the learning resource center in the middle, which is responsible for containing the data and playing the role of leader. This center connects with faculty and students with the help of technology. Whereas, it also connects the supportive departments of the university, i.e., Marketing \& Communication and Management \& Staff with the help of technology. This system is a cloud-based system that only connects the stakeholders, i.e., the teacher delivers a lecture to students, students give feedback and, managerial staff and marketing department help in case of any issue.

\section{Virtual Teaching Model Description:}

Owning to the failure of the Traditional Educational System, the only option left is the Virtual Learning Environment, which will change the educational system at 360 degrees. That system is called Cloud-Based Learning, which comprises of a "Virtual Learning Room" at home for both the Virtual Teacher and Virtual Student. Both need a well-equipped computer system and high-speed internet facility at convenience. For now, we can only confine to adopting this model without introducing the issues related to this system. 


\section{Results of Design Thinking Model:}

With the help of the Design Thinking Methodology, the researcher has identified 33 empathic paths on which universities may work and develop their plan to cope with the issue. These paths fall under the three major stakeholders.

\section{Virtual System:}

Cloud Server, Cloud Management \& Upgrading, and IT Support Department.

\section{Virtual Teacher:}

Dedicated Space at Home, Space Management, SOPs, Availability Management, Speed and Connectivity Required, Fast Speed Internet, Computer System, Students Evaluation \& Grading System, Students Progress Dashboards, Technical Support Required, Live Technical Support Department, Uploading/Transferring Data, and Downloading/Receiving Data.

\section{Virtual Student:}

Dedicated Space at Home, Space Management, SOPs, Availability Management, Speed and Connectivity Required, Fast Speed Internet, Computer System, 24/7 Help \& Contact Center, 24/7 Complaint Management Unit, Technical Support Required, Live Technical Support Department, Uploading/Transferring Data, and Downloading/Receiving Data. The detailed model is given in Figure 4.

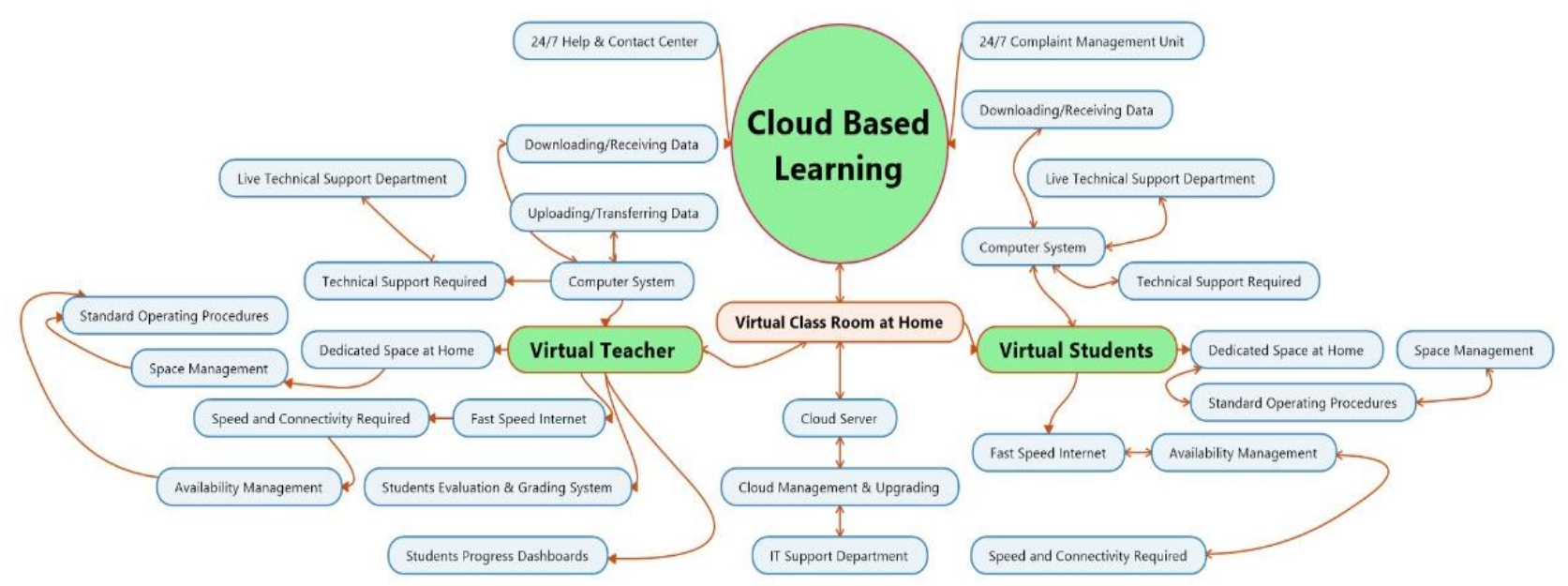

Fig. 4 Design Thinking Model - Virtual Education System

Akram \& Tabassum (2020)

\section{Policy Suggestions \& Way Forward:}

During this time, the leadership role is essential to provide a clear and motivational direction to the faculty. Concluding all, there is a need to respond as soon as possible to minimize the loss of the students. 


\section{Prototype for Planning:}

Following these scenarios and dimensions, the university must take the step and revamp its vision, mission, and objectives. It is said that we learn and do more when we take adversity as an opportunity.

\section{Responsibility:}

\section{Leadership:}

The fundamental responsibility of the leadership, in particular, to the unprecedented situation (COVID-19) when risk and uncertainty level is very high, is vital. A strategic plan is essential to inform all the departments to intact with the mission and goals of the organization. It helps the organizations to be true to the mission and focus on goals. We can use a strategic planning tool to meet the current challenges and to cope with any uncertain and risk situation in the future. This also helps to reduce frustration due to defined goals and objectives.

2. Regulatory body:

Higher Education Commission must play the role of catalyst and adapt to the changes as quickly as possible, as it is always said that "Do not wait until all the facts are in-they may never be-to act. In a crisis, good now is better than perfect later." However, at the micro-level, each university and institutions must realize that they can strategically improve their ability to respond to these shocks in the future. It will help them grow and sustain in the long run. Therefore, it is very critical for the universities to redefine their vision, mission, and objective by undertaking the scenario analysis and planning.

3. Teachers:

As teachers are demotivated, leaders must encourage them, incentivize them to learn new skills, and improve pedagogical techniques for online teaching. A humble way is to treat every faculty member as an agent of change and assign them small tasks to get connected with the students for teaching, feedback, and motivation.

4. Students:

At last, a virtual dashboard must be developed to share and monitor the activities of all stakeholders, in particular, for students, the learning curve, and the assessment. Besides, the parents must be introduced as a stakeholder of this new learning system.

5. Management and Staff:

Further, another essential step is the establishment of a dedicated center at the university that will work to collaborate internally and externally to reduce the virtual and line hindrances. For this, the introduction of an intra and inter local connectivity model for institutes and peer-to-peer learning can work. Next, the university admission and students' affair office can be used to identify their location and make phone calls individually to help them and address their issues in the best possible way.

\section{Information:}

Information plays a vital role in this system. There must be a prompt sharing of information across all stakeholders to stay updated.

\section{Quality Assurance Department:}


Along with these all academic and teacher-centric actions, there is a severe need to understand the issues at students' end. Motivation to learn online, give virtual exams, and complete assignments are the subjective variables that can only be achieved through commitment and clear communication. They are at the receiver's end, and their continuous feedback is vital in developing and improvising this new system. Therefore, their active involvement in this evolutionary process is as vital and mandatory as oxygen to humans.

\section{Controller of Examination}

The controller of examination heads the department of examination and plays the role of students' evaluation in the universities. In the virtual system, his role must be the same in organizing the fair evaluation of students. Based on this, the current vision, mission, and objectives must be devised as per the new system. Later, there is a need to carry out analysis on technology, university, HEC, students and parents, demographics and household structure, and location. Technology, in this model, determines the success and sustainability of the structure. Very precisely, economics, ethics, and technology will be integrated for the digitization of education forced by COVID19.

\section{Flow Diagram for Planning:}

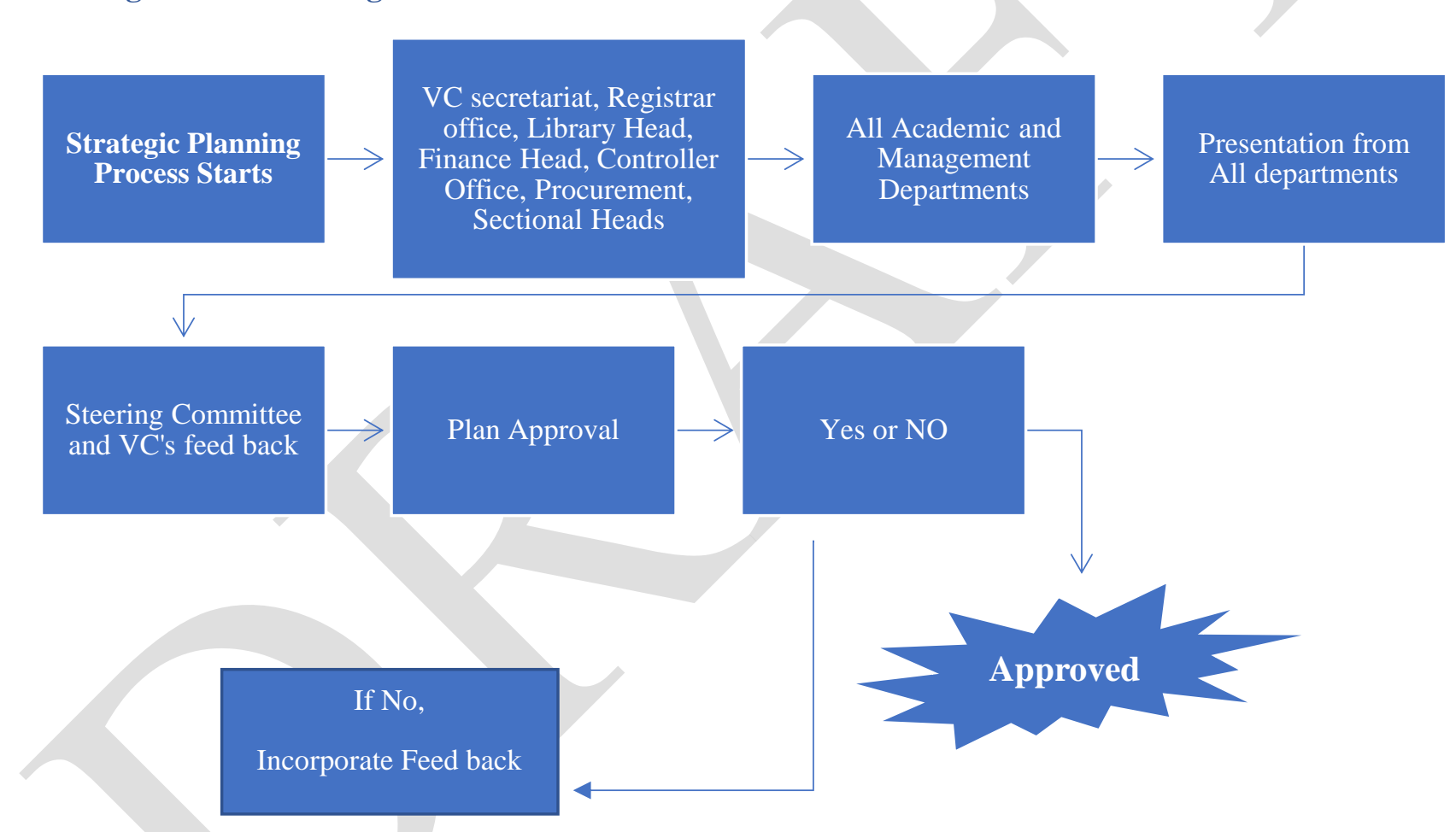

Impart Quality Education Amidst Crises (COVID - 19):

Strategic Plan:

- Goal:

There is a need to develop the goal that must impart relevant, high-quality learning opportunities for the students.

- Strategy:

The strategy of each institute must be to deliver the quality teaching with improved learning, and professional development of teachers. 
- Activities:

After understanding and working on the goal and strategy, the "Resource Center for teaching and learning online must be developed.

- Key Collaborators \& Stakeholders:

The stakeholders of this model are (1) Faculty working fulltime or part-time, (2) Staff (IT Controller Office, Quality Assurance Course Quality, and Student Evaluation), (3) Head \& sectional Heads, (4) HR Staff.

The collaboration of each department is essential.

- Human, Technology, Facilities, Equipment, or Financial Assets:

This system requires the physical space for the development and sustainability of the resource center and funds for the development of video lectures, sponsorship of speakers, purchase of webinars sessions, and hosting of seminars.

- Key Result (Success Measurement):

There must not be a rush to get instant results. This system will not deliver instantly, despite the considerable investment. The immediate results can be in the shape of the establishment of the resource center, designation of personnel for the online classes, and the platform for the online classes along with the course contents (during the two months).

The long-term results are not decided yet.

- Risk:

Like every system, this system also possesses the risks in the shape of (1) the faculty and staff may not know to serve students, and (2) the enrollment of students may decline.

\section{- Collaboration:}

Each university must develop the collaboration with the "Higher Education Commission, Pakistan, Federal Government, and Provincial Governments.

\section{Conclusion}

No doubt, the COVID - 19 outbreak has plumped the current educational system of the world. Higher Education Commission, Pakistan, is playing his role in revamping the educational system. This research undertakes the scenario analysis along with the Design Thinking Model to predict the consequences of the prevailing situation and to develop the model for the resuming of the educational system in the country. The findings of this study have given the "cloud-based virtual learning system that encompasses its three (3) main stakeholders, i.e., Virtual Teacher, Virtual Student, and Virtual System. Therefore, based on this given system, with the help of HEC, each university can develop its own virtual learning system to resume the teaching. However, in this short time, the researchers are only able to do the scenario analysis based on the brainstorming and personal experiences, where the VLE is developed based on the feedback given by students. Besides, researchers were not able to undertake the potential issues that may be created by the Virtual Learning System, and the feedback of teachers who may find this model challenging. 


\section{Declarations}

Availability of data and materials:

The responses of students used in this research paper are availing from the corresponding author only upon the request.

Competing interests:

The authors declare that they have no competing interests

Funding:

No funding was required for this research paper.

Authors' contributions:

WA has given the idea for this research, did scenario analysis, and worked on the design thinking model. He has provided the responses of students, contributed to writing and reviewing this manuscript. He is also the corresponding author. SA has helped in the scenario analysis, writing, reviewing, and submission of this manuscript. MMT has assisted in working on the design thinking model and the conceptualizing of this paper. YJ has worked on writing and reviewing this manuscript. AAC has worked on the conceptualization of this research paper, reviewing the design thing model and the drafting of this research paper. IY has worked on gathering the responses from students, reviewing, and writing the manuscript.

Acknowledgments:

The authors of this research paper are highly thankful to the students for providing their valuable responses regarding the virtual learning system. Along with this, they are also thankful to Professor Dr. Iqrar Ahmed Khan, former Vice Chancellor, UAF, Faisalabad for giving valuable suggestions to improve the article. 


\section{References:}

Abdollahi, A., Salarvand, S., \& Saffar, H. (2018). Comparing the efficacy of virtual and conventional methods in teaching practical pathology to medical students. Iranian Journal of Pathology, 13(2), 108.

Al-Neklawy, A. F. (2017). Online Embryology teaching using learning management systems appears to be a successful additional learning tool among Egyptian medical students. Annals of Anatomy-Anatomischer Anzeiger, 214, 9-14.

Amin, T., (June 12, 2019). Budget 2019-20: Allocation for education, services reduced by 20.5 percent. Retrieved from https://fp.brecorder.com/2019/06/20190612485340/. Accessed on April 05, 2020.

Ariana, A., Amin, M., Pakneshan, S., Dolan-Evans, E., \& Lam, A. K. (2016). Integration of traditional and E-learning methods to improve learning outcomes for dental students in histopathology. Journal of dental education, 80(9), 1140-1148.

Balaman, Ş. Y. (2019). Chapter 4-Sustainability Issues in Biomass-Based Production Chains. Decision-Making for BiomassBased Production Chains, 77-112.

Bervell, B., \& Arkorful, V. (2020). LMS-enabled blended learning utilization in distance tertiary education: establishing the relationships among facilitating conditions, voluntariness of use and use behaviour. International Journal of Educational Technology in Higher Education, 17(1), 1-16.

Colis, B., \& Moonen, J. (2001). Flexible learning in a digital world. Open Learning: The Journal of Open, Distance and eLearning, 17(3), 217-230

Dam, R., F., \& Teo, Y., S., (March 2020). Design Thinking Model: 5 Stages in the Design Thinking Process. Retrieved from https://www.interaction-design.org/literature/article/5-stages-in-the-design-thinking-process. Accessed on April 09, 2020.

Dávideková, M., Mjartan, M., \& Greguš, M. (2017). Utilization of virtual reality in education of employees in slovakia. Procedia computer science, 113, 253-260.

Economic Survey of Pakistan, (2018 - 19). Education. Ministry of Finance, Government of Pakistan. Retrieved from http://www.finance.gov.pk/survey_1819.html Accessed on April 09, 2020.

Fernandez, M. (2017). Augmented virtual reality: How to improve education systems. Higher Learning Research Communications, 7(1), 1-15.

Halili, S. H. (2019). Technological Advancements in Education 4.0. The Online Journal of Distance Education and eLearning, 7(1), 63.

Halili S.H., Nurul, H., \& Rafiza, A.R. (2018). Traditional versus virtual learning: How engaged are the students in learning English literature. Indonesian Journal of Applied Linguistics, 8 (1), 79-90.

Halili, S. H., Rahman, N. H. A., \& Razak, R. A. (2018). Traditional versus virtual learning: How engaged are the students in learning English literature. Indonesian Journal of Applied Linguistics, 8(1), 79-90.

Halili S.H., \& Hamidah, S. (2016). Exploring The Use Of Information And Communications Technology (Ict) In Education For Adolescents In Urban Poverty, The Online Journal of Distance Education and e-Learning, 4 (2), 31-34.

Halili S.H., \& Suguneswary, R. (2016).Teachers' Acceptance On Using Information Communication And Technology (ICT) In Teaching Tamil Language, The Online Journal of New Horizons in Education, 6 (2), 101-111.

$\begin{array}{llll}\text { Handbook } & \text { MIT } & \text { (2019). Retrieved }\end{array}$ https://www.mass.edu/foradmin/trustees/documents/FinalCampusStrategicPlanningGuidelinesProceduresAY1718.pdf. Accessed on April 04, 2020.

Hannafin, M. J., \& Hannafin, K. M. (2010). Cognition and student-centered, web-based learning: Issues and implications for research and theory. In Learning and instruction in the digital age (pp. 11-23). Springer US.

Higher Education Commission, Pakistan (2020). Recognised Universities. Retrieved From https://hec.gov.pk/english/universities/pages/recognised.aspx\#Default=\%7B\%22k\%22\%3A\%22\%22\%2C \%22r\% 
22\%3A $\% 5 \mathrm{~B} \% 7 \mathrm{~B} \% 22 \mathrm{n} \% 22 \% 3 \mathrm{~A} \% 22 \mathrm{HECUniversitySectorOWSCHCS} \% 22 \% 2 \mathrm{C} \% 22 \mathrm{t} \% 22 \% 3 \mathrm{~A} \% 5 \mathrm{~B} \% 22 \% 5 \mathrm{C} \% 2$ 2\%C7\%82\%C7\%825075626c6963\%5C \%22\%22\%5D\%2C\%220\%22\%3A \%22and\%22\%2C\%22k\%22\%3Afalse $\% 2 \mathrm{C} \% 22 \mathrm{~m} \% 22 \% 3 \mathrm{Anull} \% 7 \mathrm{D} \% 5 \mathrm{D} \% 7 \mathrm{D}$. Accessed on April 07, 2020.

Hoffman, L., (July 30, 2016). 10 Models for Design Thinking. Retrieved from https://medium.com/@elizabeth7hoffman/10models-for-design-thinking-f6943e4ee068. Accessed on April 09, 2020.

INOMICS (April 08, 2020). Coronavirus Update. Retrieved from https://inomics.com/insight/how-the-coronavirus-isaffecting-economics1452237 ?utm_source=Email\%20Alert\&utm_medium=Email\&utm_campaign=Thursday\%20Email\%20Alert. Accessed on April 09, 2020.

Kishita, Y., Nakatsuka, N., \& Akamatsu, F. (2017). Scenario analysis for sustainable woody biomass energy businesses: The case study of a Japanese rural community. Journal of Cleaner Production, 142, 1471-1485.

Martins, L. L., \& Kellermanns, F. W. (2004). A model of business school students ${ }^{\text {ee }}$ acceptance of a web-based course management system. Academy of Management Learning and Education, 3, 7-26.

Maryam, F.K., \& Halili S.H., (2015). Podcast acceptance to enhance learning science vocabulary among Iranian elementary students. The Online Journal of Distance Education and e-Learning, 3 (4), 51-60.

McKinsey (2020). Retrieved From https://www.mckinsey.com/business-functions/risk/our-insights/covid-19-implicationsfor-business?cid=other-eml-alt-mipmck\&hlkid=0c9161c2e2ed44079b452c62336fdc0c\&hctky=2033692\&hdpid=5d2d919f-402a-4cc1-bb7fcd772a29f8d0. Accessed on April 04, 2020

Means, B., Toyama, Y., Murphy, R., Bakia, M., \& Jones, K. (2009). Evaluation of evidence-based practices in online learning: A Meta-Analysis and Review of Online Learning Studies. Retrieved from https://www2.ed.gov/rschstat/eval/tech/evidence-based-practices/finalreport.pdf

Medina, F. X., Pinto de Moura, A., Vazquez-Medina, J., Frias, J., Aguilar, A., (2019). Feeding the online: perspectives on food, nutrition and the online higher education International Journal of Educational Technology in Higher Education 16, 42 (2019). https://doi.org/10.1186/s41239-019-0173-y.

Mercader, C., \& Gairín, J. (2020). University teachers' perception of barriers to the use of digital technologies: the importance of the academic discipline. International Journal of Educational Technology in Higher Education, 17(1), 1-14.

National Institute of Health, Pakistan (April 7, 2020). Coronavirus Cases in Pakistan. Accessed on April 07. 2020.

Paul N . Figa (2020). Retrieved From https://www.insidehighered.com/views/2020/03/13/using-strategic-thinking-andscenario-planning-deal-coronavirus-opinion. Accessed on April 03, 2020.

Pedersen, S., \& Liu, M. (2003). Teachers' beliefs about issues in the implementation of a student-centered learning environment. Educational Technology Research and Development, 51(2), 57-76.

Phungsuk, R., Viriyavejakul, C., \& Ratanaolarn, T. (2017). Development of a problem-based learning model via a virtual learning environment. Kasetsart Journal of Social Sciences, 38(3), 297-306.

Renz, A., \& Hilbig, R. (2020). Prerequisites for artificial intelligence in further education: identification of drivers, barriers, and business models of educational technology companies. International Journal of Educational Technology in Higher Education 17, 14. https://doi.org/10.1186/s41239-020-00193-3.

Ruiz, J. G., Mintzer, M. J., \& Rosanne, M. (2006). Leipzig. The impact of E-learning in Medical Education. Acad Med, 81, 207-212.

Rogers, C. R. (1983). Freedom to Learn for the 80's. New York: Charles E. Merrill Publishing Company, A Bell \& Howell Company.

Sarrab, M. (2019, March). Distance, Virtual, Electronic, Mobile and Ubiquitous Learning Environments: Taxonomy Study. In Proceedings of the 2019 7th International Conference on Information and Education Technology (pp. 36-43). 
Shimamoto, D. (2012). Implementing a flipped classroom: An instructional module. Presented at the Technology, Colleges, and Community Worldwide Online Conference, Honolulu, HI. Retrieved from http://scholarspace.manoa.hawaii.edu/handle/10125/22527

Song, H., \& Deng, H. (2019, March). Research on the Structure of Virtual Learning Communities under the View of Ecological Learning. In 2018 8th International Conference on Education and Management (ICEM 2018). Atlantis Press.

Trowler, V. (2010). Student engagement literature review. The Higher Education Academy. Lancaster: The Higher Education Academy. Retrieved from http://americandemocracy.illinoisstate.edu/documents/democratic-engagement-whitepaper-2_13 09.pdf

Wisniewski, C. S., \& Hortman, M .B., (2019). Comparison of pharmacy students randomized to receive drug information reference education via recording or interactive Moodle lesson. International Journal of Educational Technology in Higher Education 16, 8 (2019). https://doi.org/10.1186/s41239-019-0138-1.

World Development Indicators, (2020). Data from https://data.worldbank.org/indicator/SE.TER.ENRR?end=2018\&locations=PK\&start=2000. Accessed on April 05, 2020.

Worldometer (April 07, 2020). Coronavirus Cases: Globally. Retrieved From https://www.worldometers.info/coronavirus/ Accessed on April 07, 2020. 


\section{Appendix 1.}

\section{$\underline{\text { Points for the Way Forward: (Empathy Paths) }}$}

1. Virtual Education System:

See also: Physical Campus, Virtual Class Room at Home, 24/7 Complaint Management Unit, 24/7 Help \& Contact Center

2. Virtual Teacher

See also: Computer System, Fast Speed Internet, Dedicated Space at Home, Students Evaluation \& Grading System, $\underline{\text { Students Progress Dashboards }}$

3. Virtual Students

See also: Computer System, Fast Speed Internet, Dedicated Space at Home

4. Dedicated Space at Home

See also: Space Management

5. Computer System

See also: Technical Support Required, Uploading/Transferring Data, Downloading/Receiving Data

6. $\quad$ Fast Speed Internet

See also: Speed and Connectivity Required, Availability Management

7. Computer System

See also: Uploading/Transferring Data, Downloading/Receiving Data, Live Technical Support Department

8. Dedicated Space at Home

See also: Standard Operating Procedures

9. Technical Support Required

See also: Live Technical Support Department

10. Space Management

See also: $\underline{\text { Standard Operating Procedures }}$

11. Speed and Connectivity Required

See also: Availability Management

12. Live Technical Support Department

13. Standard Operating Procedures

14. Availability Management

15. Uploading/Transferring Data

16. Downloading/Receiving Data

17. Students Evaluation \& Grading System

18. Uploading/Transferring Data See also: Computer System

19. Downloading/Receiving Data

See also: Computer System

20. Live Technical Support Department

See also: Computer System, Technical Support Required

21. Technical Support Required 
See also: Live Technical Support Department

22. Standard Operating Procedures

See also: Dedicated Space at Home, Space Management

23. Space Management

See also: $\underline{\text { Standard Operating Procedures }}$

24. Teachers

See also: Physical Campus, Virtual Class Room at Home

25. Students

See also: Physical Campus, Virtual Class Room at Home

26. Speed and Connectivity Required

See also: Availability Management

27. Availability Management

See also: $\underline{\text { Speed and Connectivity Required, Fast Speed Internet }}$

28. Students Progress Dashboards

29. Cloud Server

See also: Cloud Management \& Upgrading

30. Cloud Management \& Upgrading

See also: IT Support Department

31. IT Support Department

32. 24/7 Complaint Management Unit

See also: Education Eco-System Existing Vs New, 24/7 Help \& Contact Center

33. 24/7 Help \& Contact Center

See also: Education Eco-System Existing Vs New 